\title{
Activated Monocytes Induce Human Retinal Pigment Epithelial Cell Apoptosis Through Caspase-3 Activation
}

\author{
Ayako Yoshida, Susan G. Elner, Zong-Mei Bian, Andrei L. Kindezelskii, \\ Howard R. Petty, and Victor M. Elner
}

Departments of Ophthalmology (W. K. Kellogg Eye Center) (AY, SGE, Z-MB, VME) and Pathology (VME), University of Michigan, Ann Arbor, and Department of Biological Sciences (ALK, HRP), Wayne State University, Detroit, Michigan

SUMMARY: Dysfunction and loss of human retinal pigment epithelial (HRPE) cells is a significant component of many ocular diseases, in which mononuclear phagocyte infiltration at the HRPE-related interface is also observed. In this study, we investigated whether HRPE cell apoptosis may be induced by overlay of IFN- $\gamma$-activated monocytes. Human monocytes primed with IFN- $\gamma$ overlaid directly onto HRPE cells elicited significant increases in terminal deoxynucleotidyl transferase-mediated dUTP nick-end labeling (TUNEL)-positive HRPE cells $(p<0.0001)$ and decreases of proliferating cell nuclear antigen-positive $(p<$ 0.0001) HRPE cells. The activated monocytes also induced HRPE cell caspase- 3 activation, which was inhibited by the caspase-3 inhibitor, Z-DEVD-fmk. However, co-incubations in which activated monocytes were prevented from direct contact with HRPE cells or in which the monocytes were separated from the HRPE cells after 30 minutes of direct contact, did not induce significant HRPE cell apoptosis. Function-blocking anti-CD18 and anti-intercellular adhesion molecule-1 (ICAM-1) antibodies significantly reduced activated monocyte-induced TUNEL-positive HRPE cells by $48 \%(p=0.0051)$ and $38 \%(p=0.046)$, respectively. Anti-CD18 and anti-ICAM-1 antibodies significantly inhibited caspase-3 activity by $56 \%(p<0.0001)$ and $45 \%(p$ $<0.0001$ ), respectively. However, antibodies to vascular cell adhesion molecule-1, TNF- $\alpha$, IL-1 $\beta$, or TNF-related apoptosisinducing ligand did not inhibit apoptosis or caspase-3 activation. Direct overlay of monocytes also induced reactive oxygen metabolites (ROM) within HRPE cells. The intracellular HRPE cell ROM production was inhibited by the anti-CD18 and anti-ICAM-1 antibodies, but not by superoxide dismutase, presumably due to its failure to penetrate into HRPE cells. Accordingly, neither superoxide dismutase nor $\mathrm{N}^{\mathrm{G}}$-monomethyl-L-arginine had significant effects on HRPE cell apoptosis or caspase-3 activation. Our results suggest that activated monocytes may induce ROM in HRPE cells through cell-to-cell contact, in part via CD18 and ICAM-1, and promote HRPE cell apoptosis. These mechanisms may compromise HRPE cell function and survival in a variety of retinal diseases. (Lab Invest 2003, 83:1117-1129).

$H$ uman retinal pigment epithelial (HRPE) cells form the outer blood-retina barrier and serve many supportive functions for the overlying neural retina. Dysfunction and/or loss of HRPE cells can cause retinal dysfunction and significant visual loss. HRPE cell alterations are a major pathologic component of many ocular diseases such as proliferative vitreoretinopathy (PVR), age-related macular degeneration (ARMD), and overtly inflammatory ocular diseases including uveitis. PVR is characterized by formation of epiretinal membranes in which HRPE cell proliferation and extracellular matrix production predominate in the early stages of the disease, whereas

\section{DOI: 10.1097/01.LAB.0000082393.02727.B5}

Received September 26, 2002.

Supported by National Institutes of Health Grants EY09441 and EY007003 and by a Research to Prevent Blindness-Olga Keith Weiss Award (to VME).

Address reprint requests to: Dr. V. M. Elner, Department of Ophthalmology (W. K. Kellogg Eye Center), University of Michigan, 1000 Wall Street, Ann Arbor, Michigan 48105.E-mail:velner@umich.edu the proportion of HRPE cells decreases in late stages of PVR (Yamashita et al, 1986). Apoptosis of HRPE cells is observed in these membranes (Esser et al, 1997). Advanced cases of ARMD and uveitis frequently show loss and degeneration of HRPE cells. Because breakdown of the blood-retina barrier is frequently seen in these diseases, HRPE cells receive signals from humoral factors, inflammatory mediators, and infiltrating leukocytes. These signals not only alter HRPE cell function and behavior but may also influence the survival and integrity of HRPE cells. Antagonistic or synergistic signals acting on HRPE cells may be important in bringing about HRPE cell death or promoting cell survival. Epidermal growth factor, basic fibroblast growth factor, platelet-derived growth factor, and TNF- $\alpha$, for example, induce HRPE cell proliferation, whereas transforming growth factor- $\beta$ has been known to cause HRPE cell apoptosis (Esser et al, 1997; Kaven et al, 2000; Kishi et al, 1994; Liu et al, 1992; Schwegler et al, 1997).

Direct cell-to-cell contact has also been shown to influence cellular response, function, and survival in many kinds of cell types (Meszaros et al, 2000; 
Seshiah et al, 2002; Yoshida et al, 2001a). HRPE cells are frequently associated with monocytes in PVR, ARMD, and uveitis (Baudouin et al, 1992; Chan et al, 1985; Harper et al, 1992; Jerdan et al, 1989; Kampik et al, 1981; Vinores et al, 1990). We previously found that direct interactions between HRPE cells and monocytes result in chemokine induction and that HRPE cell responses to cytokines differ when they are cocultured with monocytes (Yoshida et al, 2001a, $2001 b)$. Because inflammation can cause tissue destruction as well as proliferation, mononuclear phagocytes might also influence HRPE death and survival.

It is well known that monocytes and macrophages play important roles in innate immunity and inflammatory responses. Activated monocytes and macrophages have the capacity to direct apoptosis of various kinds of cells including glomerular mesangial cells, fibroblasts, neurons, smooth muscle cells, lung epithelial cells, T lymphocytes, neutrophils, endothelial cells, and tumor cells (Arantes et al, 2000; DiezRoux and Lang 1997; Duffield et al, 2000; Griffith et al, 1999; Hirano, 1998; Meszaros et al, 2000; Nakayama et al, 2000). Although quiescent macrophages can induce neuronal apoptosis (Arantes et al, 2000), cytotoxic activity of monocytes and macrophages to most cells has required monocytes and macrophage stimulation with inflammatory mediators including IFN- $\gamma$, which is known to be increased in eyes with PVR and uveitis (Griffith et al, 1999; Nakayama et al, 2000). Therefore, in these diseases, activated monocytes and macrophages may be expected to have some effects on HRPE cell death and survival. However, little is understood of signaling mechanisms by which monocytes influence HRPE cell death and survival.

The balance between cell apoptosis and survival is dependent upon the relative expression of specific genes whose products interact to determine the final outcome of apoptotic signals. Among a series of cellular events, the activation of caspases seems to be a major factor for the execution of apoptosis (Alnemri, 1997). Caspases are synthesized as inactive proenzymes that are proteolytically cleaved to an active form. Activated caspases then cleave specific target proteins at aspartic acid residues, inactivating or damaging essential cellular proteins including enzymes involved in DNA repair, structural components of the cytoplasm and nucleus, and various protein kinases (Cryns and Yuan, 1998; Thornberry and Lazebnik, 1998). Investigation of different patterns of caspase activation is an area of intensive research, and the exact contribution of individual caspases is increasingly being defined (Zheng et al, 1999). Of the caspase family members, caspase- 3 seems to be a central effector of the caspase cascade and considered by many as a final executioner of the apoptotic cell death program (Susin et al, 1997). Previous studies have shown that in HRPE cell apoptosis, caspase-3 activation is involved in hydrogen peroxide-induced, blue light exposure-induced, and zinc chelator-induced apoptosis, whereas it does not participate in ischemia-induced HRPE cell apoptosis (Hyun et al, 2001; Jin et al, 2001; Sparrow and Cai, 2001; Wood and Osborne, 2001). However, there is no information about caspase- 3 activity in HRPE cells exposed to contact with monocytes.

In this study, we examined whether IFN- $\gamma$-activated monocytes can trigger HRPE cell apoptosis. In addition, we tested the involvement of caspase-3 and characterized the cellular interactions leading to activated monocyte-induced HRPE cell apoptosis.

\section{Results}

\section{Apoptotic Index of HRPE Cells Co-Cultured with Activated Monocytes}

We investigated whether activated monocytes could induce HRPE cell apoptosis. Prelabeling of HRPE cells with Cell Tracker Green CMFDA and staining of fixed cultures with propidium iodide (PI) enabled selective assessment of HRPE cells. We could see the shape and size of HRPE cells (Fig. 1). Because apoptotic cells remain intact and closely associated within the cultures, it is possible to definitively assay apoptotic cell death without disturbing the cultures. This method reduces the risk of underestimating apoptosis, an inherent problem with certain assays of apoptosis (Duffield et al, 2000). In addition, we performed terminal deoxynucleotidyl transferase-mediated dUTP nick-end labeling (TUNEL) staining. When HRPE cells were overlaid with IFN- $\gamma$-activated monocytes, and the co-cultures were stimulated with IFN- $\gamma$, we found apoptotic HRPE cells exhibiting cell shrinkage and nuclear condensation (Fig. 1A). Such cells were also positive for TUNEL staining (Fig. 1E). No significant
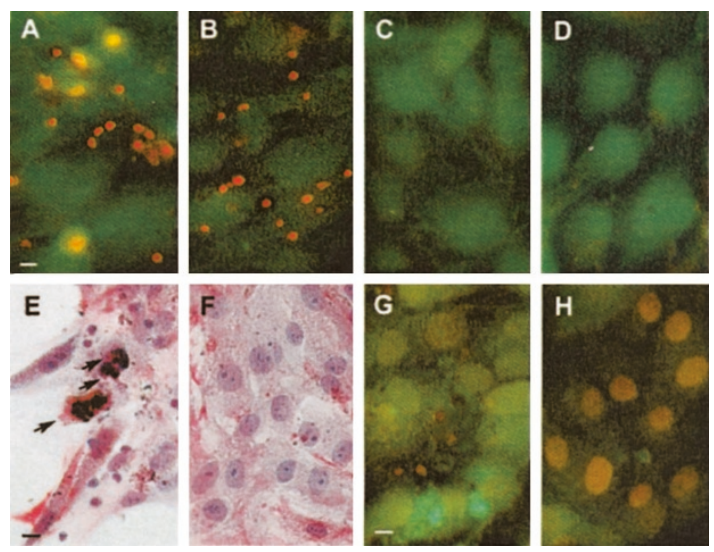

Figure 1.

Apoptosis, terminal deoxynucleotidyl transferase-mediated dUTP nick-end labeling (TUNEL) staining, and proliferating cell nuclear antigen (PCNA) immunostaining of human retinal pigment epithelial (HRPE) cell: monocyte co-cultures. A, Propidium iodide (PI) staining of 48-hour-old HRPE cell: activated monocyte co-cultures stimulated with IFN- $\gamma$ (activated co-cultures). Green HRPE cells, prelabeled with CellTracker Green CMFDA, are distinguished from monocytes, which are seen as red cells with red nuclei. HRPE cells with nuclear condensation and cell shrinkage can be seen in the activated co-cultures. B, unstimulated HRPE cell: monocyte co-cultures. C, IFN- $\gamma$ stimulated HRPE cells. D, unstimulated HRPE cells. E, TUNEL staining (brown) of activated co-cultures. HRPE cells were also stained for vimentin (red). F, TUNEL staining of HRPE cells alone stimulated with IFN- $\gamma$. G, PCNA immunostaining (red) of HRPE cells in activated co-cultures is reduced when compared with IFN- $\gamma$-stimulated HRPE cells alone as seen in H. HRPE cells were prelabeled with CellTracker Green CMFDA before co-culture. Bar $=20 \mu \mathrm{m}$. 
difference between the percentages of cells demonstrating nuclear condensation on PI staining and those labeled with TUNEL was seen in the co-cultures $(25.3$ \pm 4.1 vs $23.7 \pm 3.4 \%$ ). Proliferating cell nuclear antigen (PCNA), which has been shown to be a useful marker for proliferating cells, was also assessed after overlay of monocytes onto HRPE cells. When monocytes were primed with IFN- $\gamma$, and the subsequent co-cultures were stimulated with IFN- $\gamma$ (activated cocultures), significant increases in TUNEL-positive HRPE cells $(p<0.0001)$ and decreases in PCNApositive cells $(p<0.0001)$ were observed compared with control culture of HRPE cells growing alone, stimulated with IFN- $\gamma$ (Fig. 2). When unstimulated monocytes were overlaid onto HRPE cells and the co-cultures were incubated without IFN- $\gamma$ (unstimulated co-cultures), TUNEL-positive HRPE cells were not induced and PCNA-positive HRPE cells were increased compared with unstimulated HRPE cells (Fig. 2). HRPE cells alone, stimulated with IFN- $\gamma$, did not undergo apoptosis and demonstrated significant increases in PCNA-positive cells $(p=0.0025)$ compared with unstimulated HRPE cells.

Priming of both HRPE cells and monocytes with IFN- $\gamma$ did not result in significant increases in the number of TUNEL-positive HRPE cells compared with monocyte priming alone (Table 1). When neither HRPE cells nor monocytes were primed or when only HRPE cells were primed, co-cultures stimulated with IFN- $\gamma$ induced $48 \%$ and $52 \%$ HRPE cell apoptosis, respectively, compared with monocyte priming.

\section{Caspase-3 Activation in HRPE Cells Induced by Activated Monocytes}

We examined the involvement of caspase-3 in IFN- $\gamma$ activated monocyte-induced HRPE cell apoptosis. We quantitated caspase- 3 activity in HRPE cell lysates by measuring the cleavage of the caspase-3-specific substrate Ac-DEVD-pNA. Caspase-3 activity was not detected in HRPE cells alone, with or without IFN- $\gamma$ stimulation (Fig. 3A). Unstimulated co-cultures did not show significant differences in HRPE cell caspase-3 activity compared with control HRPE cells (Fig. 3A). When monocytes were primed, however, co-cultures stimulated with IFN- $\gamma$ exhibited significant $(p<$ $0.0001)$, time-dependent increases of caspase-3 activity in HRPE cells. Immunoblotting analysis also showed that the cleavage of procaspase-3 (p20) was detected in HRPE cells in activated co-cultures (Fig. 3B). When the co-cultures were incubated for 24 hours with Z-DEVD-fmk, a caspase-3 inhibitor, caspase-3 activation was significantly inhibited by $80 \%$ (Fig. 3C). This inhibitor also significantly decreased TUNEL-positive cells by $71 \%$ (Fig. 3C). When both HRPE cells and monocytes were primed with IFN- $\gamma$, caspase-3 activity of HRPE cells in co-cultures was not significantly different from that with only monocyte priming (Table 2). When neither HRPE cells nor monocytes or when only HRPE cells were primed, caspase -3 activity was only $22 \%$ and $24 \%$ of that in co-cultures with monocyte priming, respectively.

\section{A}

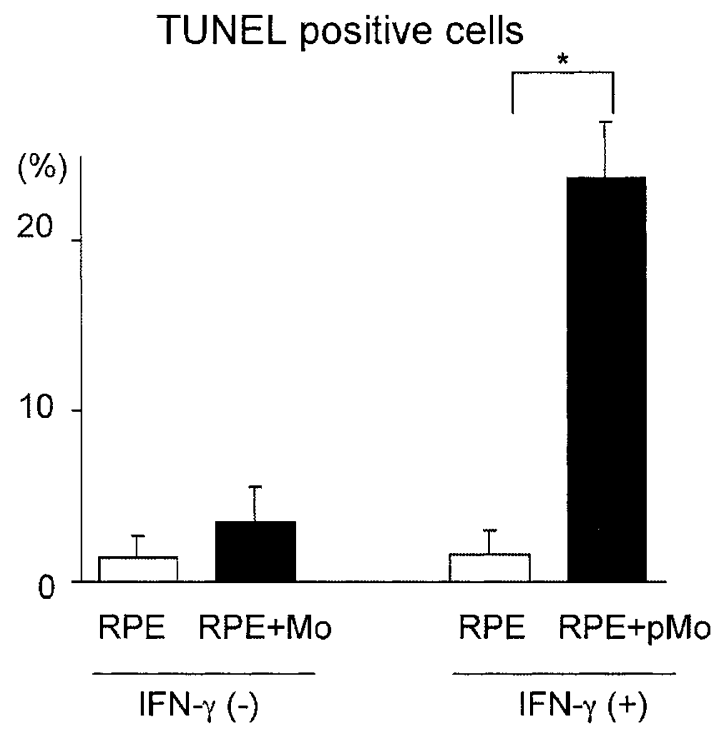

B

\section{PCNA positive cells}

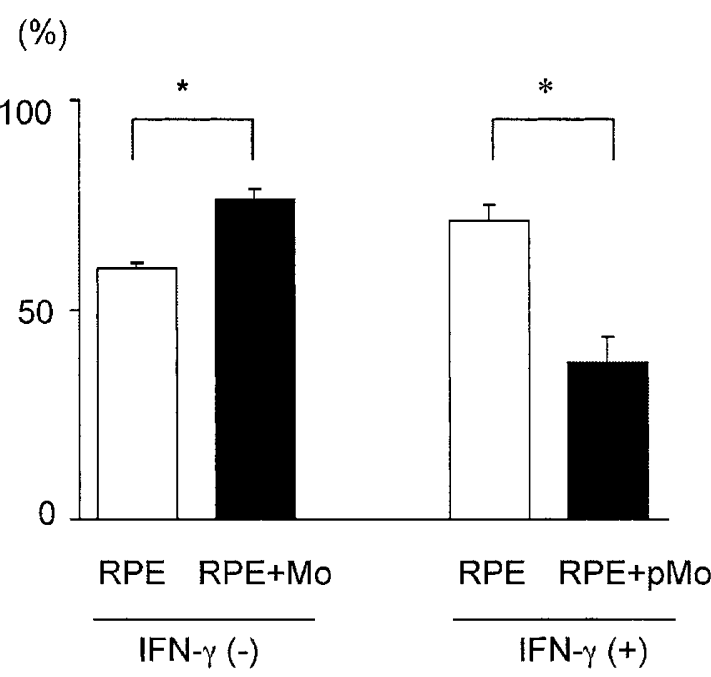

Figure 2

Quantitation of effects of co-culture of HRPE cells with activated monocytes on HRPE cell TUNEL and PCNA staining. Monocytes were primed with IFN- $\gamma$ $(p M o)$ or left unstimulated $(M 0)$ before co-culture established as described in "Materials and Methods." In activated co-cultures, co-cultures were also stimulated with IFN- $\gamma$. A, TUNEL staining of HRPE cells and monocytes. B, PCNA immunostaining of HRPE cells and monocytes. Data are expressed as percentage of TUNEL-positive HRPE cells and PCNA-positive HRPE cells. Values represent means $\pm \mathrm{SD} ;{ }^{*} p<0.05$

By increasing the ratios of monocytes to HRPE cells in activated co-cultures, a progressively greater proportion of HRPE cells showed apoptosis (Fig. 4A). Consistent with this result, HRPE cell caspase-3 activity increased as the ratio of IFN- $\gamma$-activated monocytes to HRPE cells increased (Fig. 4B). 
Table 1. Effects of IFN- $\gamma$ Pretreatment on HRPE cell TUNEL Staining

\begin{tabular}{lc}
\hline & TUNEL-positive HRPE cell $(\%)$ \\
\hline RPE + Mo & $11.4 \pm 4.8$ \\
pRPE + Mo & $12.4 \pm 3.0$ \\
pRPE + pMo & $20.83 \pm 4.8$ \\
RPE + pMo & $23.7 \pm 3.4$ \\
\hline
\end{tabular}

pRPE, HRPE cells primed with IFN- $\gamma$; pMo, monocytes primed with IFN- $\gamma$; Cocultures were incubated with IFN- $\gamma$ for 48 hours.
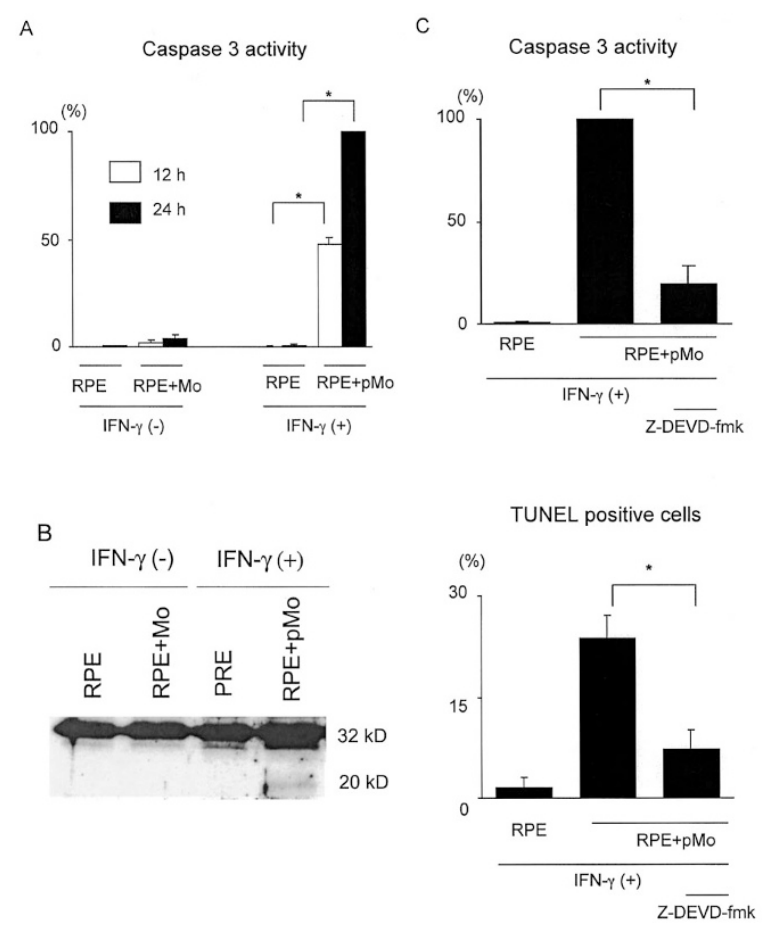

Figure 3.

Effects of co-culture of HRPE cells with activated monocytes on caspase-3 activation. Monocytes were primed with IFN- $\gamma(p M o)$ or left unstimulated $(M o)$ before co-culture established as described in "Materials and Methods." In activated co-cultures, co-cultures were also stimulated with IFN- $\gamma$. A, Caspase-3 activity was measured after 12 and 24 hours of co-culture. Activity is expressed as percent of maximal activity occurring in activated 24-hour co-cultures. B, Cell lysates were prepared after 24 hours of co-culture and Western blot analysis was performed. C, Z-DEVD-fmk (100 nmol/ml) was incubated with HRPE cells for 1 hour before addition of monocytes. Caspase-3 activity was measured after 24 hours of co-culture and is expressed as the percent activity compared with activated co-cultures without treatment with Z-DEVD-fmk (top). TUNEL staining was performed (bottom). Percentage of TUNEL-positive HRPE cells was counted. Values represent means $\pm \mathrm{SD} ;{ }^{*} p<$ 0.05 .

\section{Role of Cell-to-Cell Contact in Activated Monocyte-Induced HRPE Cell Apoptosis}

We examined whether cell contact was obligatory for HRPE cell apoptosis in activated co-cultures. Coincubation of HRPE cells and activated monocytes in the same cultures, but separated by porous polycarbonate filters, did not significantly induce apoptosis or caspase-3 activation of HRPE cells (Fig. 5). When HRPE cells and activated monocytes were cocultured for 30 minutes, and then monocytes were
Table 2. Effects of IFN- $\gamma$ Pretreatment on HRPE Cell Caspase-3 Activity

\begin{tabular}{lrc}
\hline & \multicolumn{2}{c}{ HRPE cell caspase-3 activity } \\
& \multicolumn{1}{c}{ (\%) } \\
\cline { 2 - 3 } & \multicolumn{1}{c}{$12 \mathrm{~h}$} & $24 \mathrm{~h}$ \\
\hline $\mathrm{RPE}+\mathrm{Mo}$ & $7.3 \pm 1.2$ & $22.3 \pm 2.0$ \\
$\mathrm{pRPE}+\mathrm{Mo}$ & $14.7 \pm 1.9$ & $23.8 \pm 4.8$ \\
$\mathrm{pRPE}+\mathrm{pM} 0$ & $42.8 \pm 5.7$ & $91.2 \pm 7.1$ \\
$\mathrm{RPE}+\mathrm{pM0}$ & $48.1 \pm 2.6$ & 100 \\
\hline \multicolumn{2}{l}{ Cocultures were incubated with IFN- $\gamma}$.
\end{tabular}

removed, no significant induction of apoptosis or caspase- 3 activation of HRPE cells was measured.

\section{Involvement of CD18 and Intercellular Adhesion Molecule-1 (ICAM-1) in HRPE Cell Caspase-3 Activation and Apoptosis Caused by Activated Monocytes}

We investigated whether adhesion or cytokine pathways contributed to the apoptosis and caspase- 3 activation induced in activated co-cultures. When function-blocking anti-CD18 and anti-ICAM-1 antibodies were included in activated co-cultures, HRPE cell apoptosis was significantly decreased by $48 \%$ ( $p$ $=0.0051)$ and $38 \%(p=0.046)$, respectively (Fig. $6 \mathrm{~A})$. Anti-CD18 and anti-ICAM-1 antibodies also significantly inhibited HRPE cell caspase- 3 activity by $56 \%$ $(p<0.0001)$ and $45 \%(p<0.0001)$, respectively (Fig. $6 \mathrm{~B})$. These inhibitory effects were not significantly enhanced by preincubation of the HRPE cells and/or monocytes with the antibodies before co-culture (data not shown). When these antibodies were removed after preincubating them with activated monocytes and HRPE cells before co-culture, none of these antibodies significantly inhibited the caspase-3 activation (not shown). Function-blocking antibodies to vascular cell adhesion molecule-1 (VCAM-1), TNF- $\alpha$, IL-1 $\beta$, or TNF-related apoptosis-inducing ligand (TRAIL) did not inhibit the caspase-3 activation or apoptosis.

\section{Intracellular Reactive Oxygen Metabolite (ROM) Production in HRPE Cells Co-Incubated with Activated Monocytes}

To assess whether ROM may be associated with IFN- $\gamma$-activated monocyte-induced HRPE cell apoptosis, we visualized ROM in HRPE cells after activated monocyte contact. We observed intracellular ROM production in HRPE cells co-incubated with activated monocytes (Fig. 7). This intracellular ROM production was inhibited by anti-CD18 and antiICAM-1 antibodies by $61 \%$ and $35 \%$, respectively (Fig. 7B). In contrast, the antioxidant, superoxide dismutase (SOD) $(100 \mathrm{U} / \mathrm{ml}$ and $1000 \mathrm{U} / \mathrm{ml})$, did not affect this HRPE cell intracellular fluorescence, presumably because of its failure to penetrate into the cells. Likewise SOD did not have significant effects on apoptosis or caspase-3 activation of HRPE cells (not shown). We also tested the involvement of nitric oxide 
A

(\%)

TUNEL positive cells

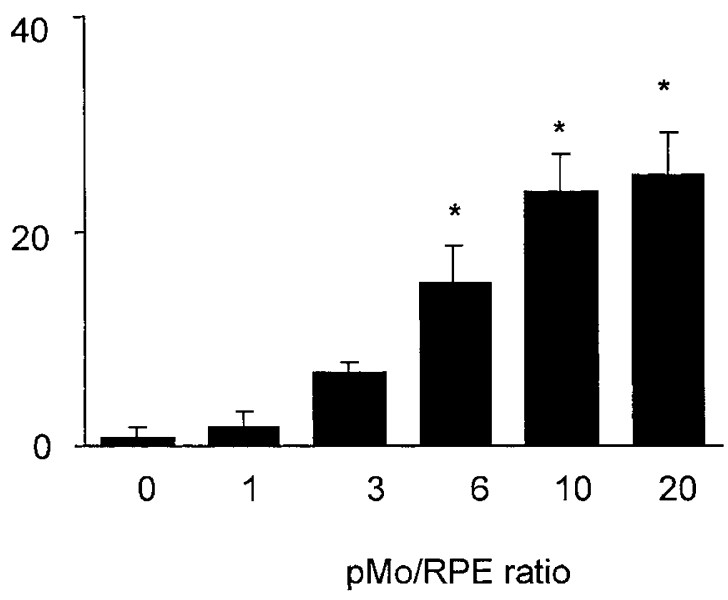

B

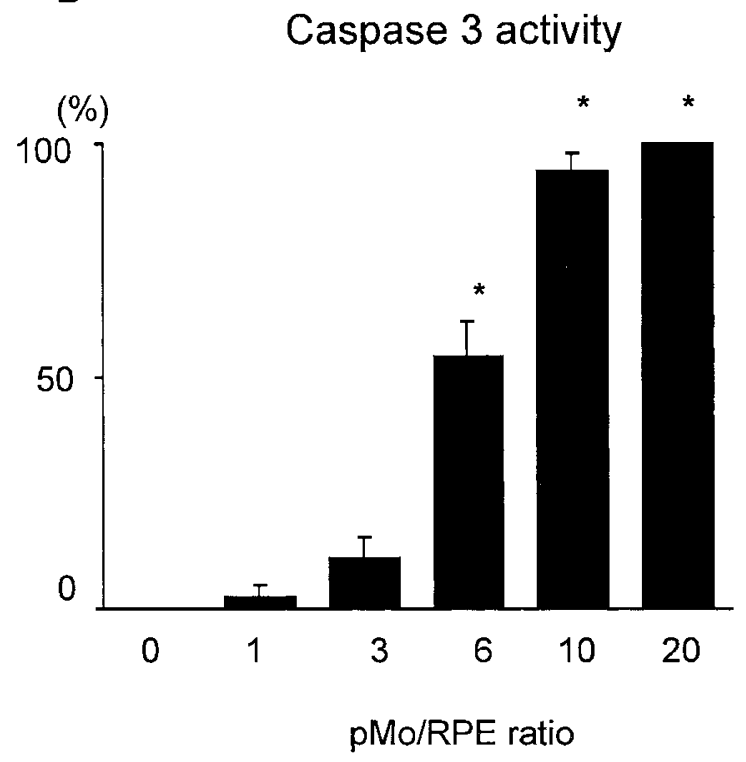

Figure 4.

Effects of ratios of monocytes to HRPE cells in co-cultures on TUNEL positivity and caspase- 3 activity. Monocytes were primed with IFN- $\gamma$ for 12 hours $(p M o)$, and then co-cultures were stimulated with IFN- $\gamma$. A, After 48 hours of co-culture, percentage of TUNEL-positive HRPE cells was counted. B, Caspase- 3 activity was measured after 24 hours of co-culture and is expressed as percent activity compared with maximum activity (monocytes/HRPE cells $=$ 20). Values represent means $\pm \mathrm{sD} ;{ }^{*} p<0.05$, compared with control.

(NO) in HRPE cell apoptosis in activated co-cultures. A NO inhibitor, $N^{G}$-monomethyl-L-arginine (L-NMMA), did not affect the apoptosis or caspase-3 activation (not shown).

\section{Discussion}

The blood-retina barrier limits access of inflammatory cells and molecules into the eye. Breakdown of the
A

TUNEL positive cells
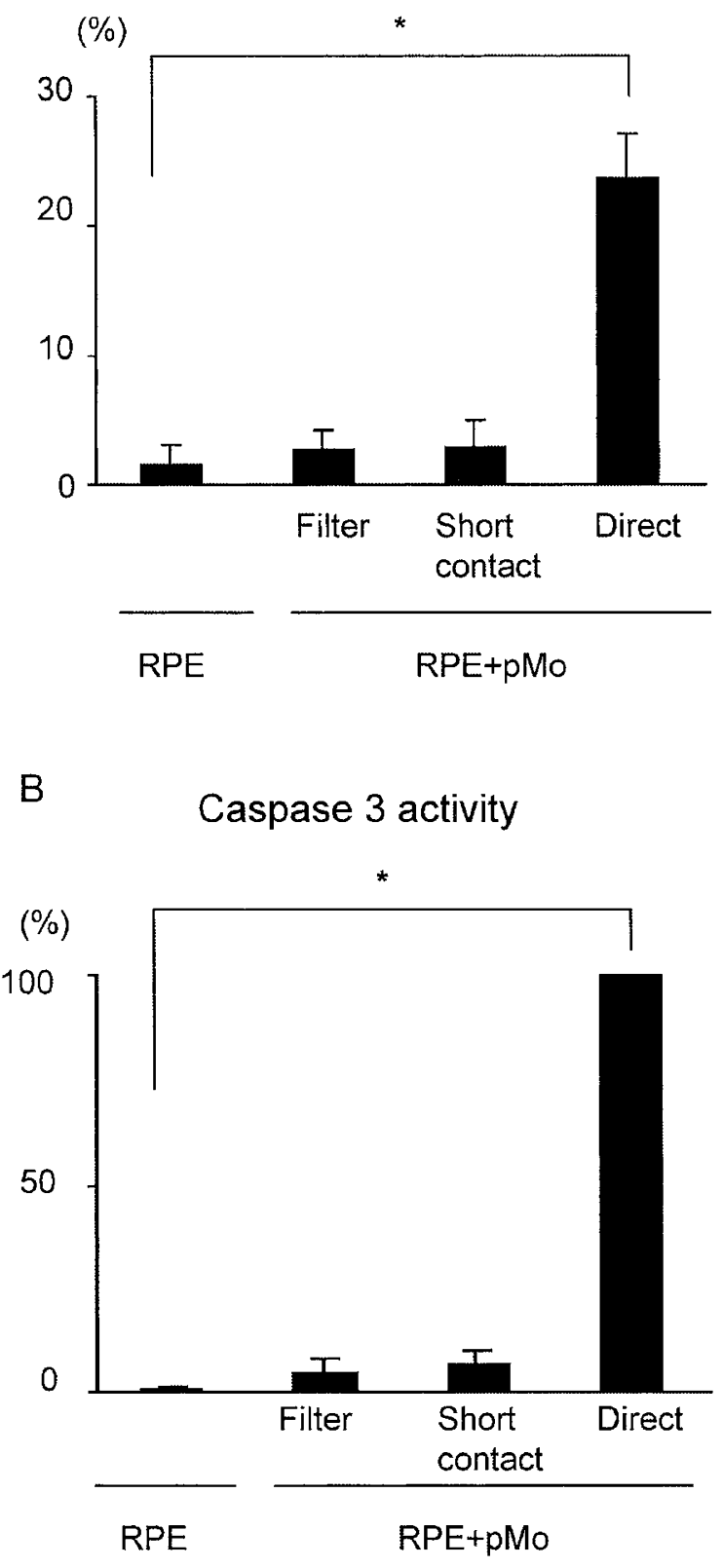

Figure 5.

Role of cell-cell contact in activated monocyte-induced HRPE cell apoptosis Monocytes were overlaid directly onto HRPE cells (Direct), or co-incubated with HRPE cells in the same cultures but separated by porous polycarbonate filters (Filter), or overlaid directly onto HRPE cells for 30 minutes and then detached from HRPE cells (Short contact). A, After 48 hours of co-culture, percentage of TUNEL-positive HRPE cells was counted. B, Caspase-3 activity was measured after 24 hours of co-culture and expressed as percent activity compared with co-cultures in which monocytes were directly overlaid onto HRPE cells for the entire 24-hour period. Values represent means $\pm \mathrm{SD}$; ${ }^{*} p<$ 0.05

outer blood-retina barrier and monocytic infiltration are prominent features of PVR, ARMD, and uveitis. HRPE cells and monocytes are closely associated in the histopathologic lesions of eyes with these dis- 


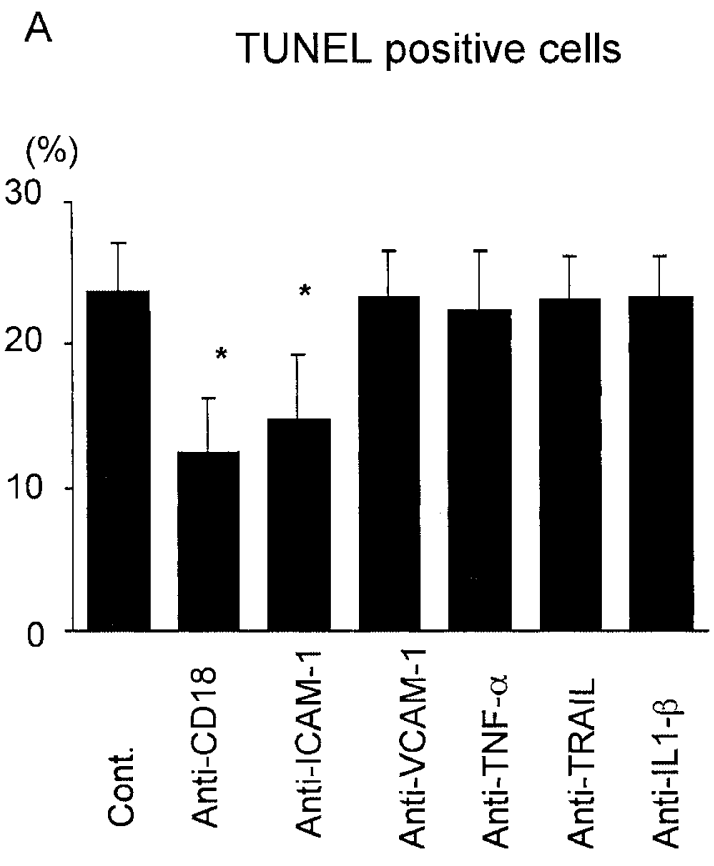

B Caspase 3 activity

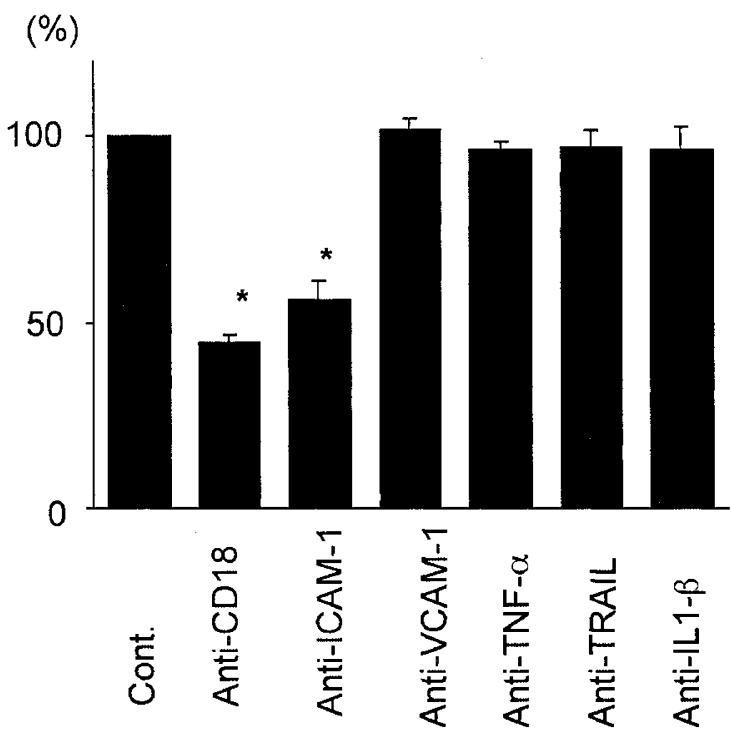

Figure 6.

Role of adhesion molecules and cytokines in activated monocyte-induced HRPE cell apoptosis. Monocytes were primed with IFN- $\gamma$, and then co-cultures were stimulated with IFN- $\gamma$. Antibodies directed against CD18, intercellular adhesion molecule-1 (ICAM-1), vascular cell adhesion molecule-1 (VCAM-1), TNF- $\alpha$, TNF-related apoptosis-inducing ligand, and IL-1 $\beta$ were incubated with HRPE cells and monocytes. A, Percentage of TUNEL-positive HRPE cells was counted. B, Caspase- 3 activity was measured after 24 hours of co-culture and expressed as percent activity compared with control co-cultures. Values represent means $\pm \mathrm{SD} ;{ }^{*} p<0.05$, compared with control.

eases (Baudouin et al, 1992; Chan et al, 1985; Harper et al, 1992; Jerdan et al, 1989; Kampik et al, 1981; Vinores et al, 1990). There is increasing evidence that both monocytes and HRPE cells have critical regula-
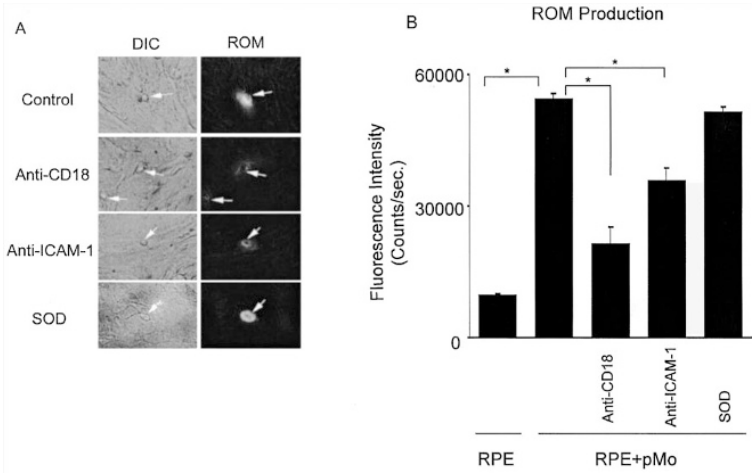

Figure 7.

Production of reactive oxygen metabolites (ROM) in HRPE cells co-cultured with activated monocytes. Monocytes were primed with IFN- $\gamma$, and then co-cultures were stimulated with IFN- $\gamma$. Anti-CD18 and anti-ICAM- 1 antibodies and superoxide dismutase $(100 \mathrm{U} / \mathrm{ml})$ were incubated with HRPE cells and monocytes. A, Differential image contrast $(D I C)$ photomicrographs (left) and fluorescence photomicrographs (ROM) (right) of co-cultures in which HRPE cells were preincubated with dihydrotetramethylrosamine (H2TMRos). B, Fluorescence intensity was quantitated. Values represent mean fluorescence/ cell $\pm \mathrm{SD} ;{ }^{\star} p<0.05$.

tory functions in these diseases processes and that monocytes and monocyte-derived cytokines can modulate HRPE functions and integrity (Elner et al, 1990, 1991; Jaffe et al, 1995).

In eyes with PVR and uveitis, IFN- $\gamma$ is known to be up-regulated, whereas activated T-lymphocytes, which produce IFN- $\gamma$, have been identified in lesions of ARMD (Kenarova et al, 1997; Ongkosuwito et al, 1998; Reddy et al, 1995). IFN- $\gamma$ has effects on cell survival and death by itself (Brysk et al, 1995; Zachrisson et al, 2001). This is the first study, to our knowledge, in which IFN- $\gamma$-activated monocytes have been shown to induce HRPE cell apoptosis. When HRPE cells were co-cultured with monocytes activated with IFN- $\gamma$, we observed HRPE cell shrinkage, nuclear condensation, and cytoplasmic blebbing. Activated monocytes also induced increases in TUNELpositive HRPE cells and decreased percentages of PCNA-positive cells. These effects were enhanced by increasing the ratios of activated monocytes to HRPE cells in the co-cultures. In contrast, unstimulated monocytes did not induce HRPE cell apoptosis. In addition, increases in PCNA-positive HRPE cells were observed during co-culture with unstimulated monocytes, suggesting that when unstimulated, monocytes may actually enhance HRPE cell proliferation, which is consistent with previous observations (Osusky and Ryan, 1996). These data suggest that activated monocytes could cause HRPE cell apoptosis and that the tissue milieu, including the presence of cytokines and numbers of infiltrating cells, might also change how monocytes function to modulate HRPE cell proliferation or demise.

Previous studies have also reported the effects of mononuclear phagocytes on cell death and survival. Lang and Bishop (1993) have demonstrated a key role for macrophage-directed apoptosis in the elimination of unwanted capillaries in neonatal development of the mouse and rat eye. Monocytes activated with IFN- $\gamma$ 
and lipopolysaccharide also show cytotoxicity to vascular endothelial cells (Peri et al, 1990). However, unstimulated monocytes have been reported to prevent apoptosis in serum-starved vascular endothelial cells and, in fact, induce proliferation of the cells in vitro (Noble et al, 1999). Monocytes also may alternatively induce mesangial cell apoptosis and proliferation depending on the state of monocytic activation (Duffield et al, 2000; Mene et al, 2002). In this study, activated but not quiescent monocytes induced HRPE cell apoptosis, whereas quiescent monocytes induced HRPE cell proliferation. Therefore, a critical prerequisite for how monocytes participate in sustaining or eliminating resident cells, including HRPE cells, seems to be the state of monocyte activation. Such monocyte-mediated regulation of resident cell populations is probably important in numerous diseases and over a wide range of disease activity or quiescence.

Apoptosis is mediated by multiple pathways that involve a complex array of biochemical regulators and molecular interactions. Among them, involvement of caspase- 3 activation in apoptosis of various kinds of cells has been reported, implicating caspase- 3 is a major execution protease. The cleavage of caspase-3 from its proactive form to its active form has been shown to be critical for its role in apoptosis (Fernandes-Alnemri et al, 1994). The caspase-3-dependent pathway is observed in tumor cell-induced apoptosis of $\mathrm{T}$ lymphocytes and endothelial cells, whereas caspase-3 activation is not seen in HIVinfected cell-induced apoptosis (Gastman et al, 2000; Kebers et al, 1998). In this study, caspase-3 activity in HRPE cells increased as co-incubation times with activated monocytes increased. Consistent with this result, Western blot analysis of HRPE cell lysates revealed cleaved caspase- 3 induction after co-culture with activated monocytes. The caspase- 3 activation and apoptosis in HRPE cells were prevented by the caspase-3 inhibitor, Z-DEVD-fmk. These data suggest that caspase- 3 is likely to play a dominant role during activated monocyte-induced HRPE apoptosis.

Activated monocyte-induced HRPE cell apoptosis also seems to be dependent on cell-to-cell contact, because co-incubation of HRPE cells and monocytes in the same cultures, but separated by porous polycarbonate filters, does not induce the HRPE cell apoptosis observed after direct overlay of human monocytes onto HRPE cells. Short contact (30 minutes) also did not induce HRPE cell apoptosis, suggesting that continuous contact is important in the apoptosis induction. There is increasing evidence that integrins have an important role in regulation of cell death and survival (Frisch and Ruoslahti, 1997). In this study, activated monocyte-induced HRPE cell apoptosis was reduced by anti-CD18 ( $\beta 2$ integrin) antibody. Our result is in agreement with previous reports that have shown the involvement of $\beta 2$ integrins in smooth muscle cell apoptosis induced by monocytes activated with macrophage colony-stimulating factor; in HLA-DR-mediated monocyte apoptosis; in Fasmediated, monocyte-dependent, T Iymphocyte apo- ptosis; in superantigen-induced death of specific $\mathrm{CD}^{+}{ }^{+}$T-lymphocytes; and in TNF- $\alpha$-induced neutrophil apoptosis (Damle et al, 1993b; Seshiah et al, 2002; Thibeault et al, 1999; Walzog et al, 1997; Wu et al, 1996). Previous studies have shown that the CD18ICAM-1 adhesion pathway is important in the recognition of target cells and in monocyte-induced cytotoxicity of vascular endothelial cells and tumor cells (Bernasconi et al, 1991; Jonjic et al, 1992). In contrast, Noble et al (1999) demonstrated that the contactmediated monocyte signaling that protects serumstarved endothelial cells from apoptosis is not inhibited by anti-CD18 antibody, suggesting that different signals are mediated by distinct pathways. In this study, we demonstrated that anti-ICAM-1 antibody also reduced caspase- 3 activation and apoptosis of HRPE cells in response to co-incubation with IFN- $\gamma-$ activated monocytes. Our data indicate that $\beta 2$ integrin and ICAM-1 binding is likely to be an important adhesive interaction in contact-dependent HRPE cell apoptosis.

$\beta 2$ integrins are important in inflammatory responses because they mediate leukocyte aggregation, leukocyte-endothelial cell and leukocyte-tissue cell adhesion, complement binding, and binding of microbial agents (Elner et al, 1981; Elner and Elner, 1996). Although Wang et al (1994) reported IFN- $\gamma$ enhanced CD18 expression in monocytes, there are conflicting data regarding the IFN- $\gamma$ up-regulation of CD18 expression (Bernasconi et al, 1991). Nonetheless, the augmented, CD18-dependent binding of activated monocytes to target cells has been shown to depend upon changes in the avidity of these molecules rather than upon increases in the absolute numbers of these receptors on the cell surface (Elner and Elner, 1996). Thus, it is possible that activated forms of these integrins mediate avid binding of activated leukocytes to vascular endothelial cells or to cells in tissue that expresses complementary ligands.

The susceptibility of the target cells as well as the type of triggering signal dictate apoptotic mechanisms. IFN- $\gamma$ has been demonstrated to increase susceptibility of mesangial cells and placental syncytiotrophoblasts to activated monocytes (Duffield et al, 2000; Garcia-Lloret et al, 2000). The increased susceptibility of placental syncytiotrophoblasts caused by IFN- $\gamma$ is a result of an increase of ICAM-1 expression. ICAM-1-transfected melanoma cells also show augmented susceptibility to cytotoxicity by activated monocytes. ICAM-1 was detected in HRPE cells in vitro and in the eyes of experimental uveitis and ARMD (Elner et al, 1992; Kim et al, 1995; Shen et al, 1998). However, although we previously demonstrated that IFN- $\gamma$ could enhance ICAM-1 expression on the surface of HRPE cells (Elner et al, 1992), in this study, priming HRPE cells with IFN- $\gamma$ did not show significant effects on the induction of caspase-3 activation or apoptosis in HRPE cells in co-cultures with activated monocytes. Therefore, monocyte activation rather than HRPE cell susceptibility seems to be more important in CD18 and ICAM-1 involvement in HRPE cell apoptosis induced by activated monocytes. In this 
vein, robust proliferating HRPE cells in PVR membranes show strong $\beta 2$ integrin expression, whereas HRPE cells in control retinas are weakly positive for $\beta 2$ integrin (Robbins et al, 1994). ICAM-1 stimulation is also known to induce caspase-3 activation and apoptosis in T lymphocytes (Damle et al, 1993a; Palmer et al, 2001). Damle et al (1993a) demonstrated that engagement of T-lymphocyte integrins, including CD18, by their ligands is an important step during induction of T-lymphocyte death. ICAM-1 on monocytes, up-regulated by IFN- $\gamma$, thus might also be involved in apoptosis of CD18-positive HRPE cells (Elner et al, 1981).

In previous studies, TNF- $\alpha$ has been considered to play a major role in activated monocyte-induced and macrophage-induced apoptosis in many cells including neutrophils, mesangial cells, and placental syncytiotrophoblasts (Duffield et al, 2000; Feinman et al, 1987; Garcia-Lloret et al, 2000; Meszaros et al, 2000). Griffith et al (1999) reported that activated monocyteinduced cytotoxicity of tumor cells is mediated by TRAIL. However, in this study, function-blocking antiTNF- $\alpha$, anti-IL- $1 \beta$, or anti-TRAIL antibodies did not inhibit the caspase-3 activation or apoptosis of HRPE cells induced by activated monocytes. Therefore, these factors do not seem to be involved in activated monocyte-induced HRPE cell apoptosis. Our data are supported by the report that TNF- $\alpha$ alone did not induce HRPE cell apoptosis even though it possesses cytotoxic activity to many other cell types (Harris et al, 1996).

ROM are also considered to be the major mediator of neutrophil-induced cytotoxicity of corneal epithelial cells, monocyte-induced apoptosis in natural killer cells, transforming growth factor- $\beta$-induced apoptosis of fibroblasts, and IFN- $\alpha$-activated and IFN- $\gamma$ activated monocyte cytotoxicity of tumor cells (Hansson et al, 1996; Matsumoto et al, 1998; Von Eynatten and Bauer, 2001; Webb and Gerrard, 1990). ROM are also known to induce HRPE cell apoptosis and be implicated in the development of uveitis, ARMD, and PVR (Barak et al, 2001; Beatty et al, 2000; Boker et al, 1994; Rao et al, 1987). In our study, activated monocytes induced ROM production in HRPE cells before apoptosis induction. Anti-CD18 and anti-ICAM-1 antibodies significantly reduced the intracellular ROM induction. However, SOD did not affect intracellular ROM induced by activated monocytes, presumably because of its failure to penetrate into HRPE cells (Drunat et al, 2001; Wang et al, 1996). SOD also did not have significant effects on apoptosis or caspase-3 activity in HRPE cells induced by activated monocytes. Intracellular formation of ROM is known to be more important to apoptosis induction than extracellular addition of ROM (Ramachandran et al, 2002). Therefore, although IFN- $\gamma$ also induces monocyte ROM release (Salisbury and Calhoun, 1990), this is unlikely to have a significant role in HRPE cell apoptosis because SOD did not inhibit HRPE cell apoptosis in our study. In contrast, intracellular ROM in HRPE cells induced by the contact of activated monocytes via adhesion molecules, not susceptible to SOD, may well be involved in HRPE cell apoptosis.

Involvement of NO has also been shown in activated monocyte cytotoxicity (Duffield et al, 2000). However, an NO inhibitor, L-NMMA, did not inhibit HRPE cell apoptosis induced by activated monocytes. Although NO has been shown to inhibit HRPE cell growth and cause retinal damage, NO produced by RPE cells stimulated with IFN- $\gamma$ and lipopolysaccharide could not induce RPE cell apoptosis (Behar-Cohen et al, 1996; Goureau et al, 1993). Our data, together with these observations, suggest that NO does not play a significant role in the monocyte cytotoxic activity of HRPE cells.

Our data indicate that there are specific mechanisms in activated monocyte-induced HRPE cell apoptosis, which exhibits some properties in common with apoptosis of other cell types. Our observations provide evidence for a new concept in blood-retina barrier breakdown, monocyte-directed regulation of HRPE cell populations by the coordinated induction of apoptosis. In other tissues, new investigations have shown monocyte/macrophage-directed regulation of mesangial cells in glomerulonephritis and of smooth muscle cells in atherosclerotic plaques (Duffield et al, 2000; Seshiah et al, 2002). Monocyte-induced HRPE cell survival and death also play a pivotal role in the outcome of inflammatory responses seen in numerous retinal diseases. This study may provide a novel molecular mechanism for the regulation of HRPE monolayer integrity in ocular diseases.

\section{Materials and Methods}

\section{Reagents}

Falcon Primaria flasks were purchased from Becton Dickinson Inc. (Lincoln Park, New Jersey). Plates, dishes, and transwell chambers were purchased from Costar (Kennebunkport, Maine). Plastic coverslips were purchased from Nalge Nunc International (Rochester, New York). Recombinant human (rh) IFN- $\gamma$, antibodies against ICAM-1, VCAM- 1 , TNF- $\alpha$, IL- $1 \beta$, and TRAIL were purchased from R\&D Systems (Minneapolis, Minnesota). Anti-CD18 antibody was purchased from Immunotech, Inc. (Westbrook, Maine). Rabbit polyclonal anti-caspase-3 antibody was purchased from Santa Cruz Biotechnology (Santa Cruz, California). DMEM, $\mathrm{Ca}^{2+}, \mathrm{Mg}^{2+}$-free PBS, fetal bovine serum (FBS), Triton X-100, sodium chloride, glycerol, magnesium chloride, EDTA, sodium orthovanadate, sodium pyrophosphate, AEBSF [4-(2-aminoethyl)benzenesulfonyl fluoride], sodium fluoride, aprotinin, $\mathrm{PI}, \mathrm{SOD}$, and catalase were purchased from Sigma Chemical Company (St. Louis, Missouri). In Situ Cell Death Detection, POD was purchased from Roche Molecular Biochemicals (Indianapolis, Indiana). The Caspase-3 Cellular Activity Assay Kit was purchased from Biomol (Plymouth Meeting, Pennsylvania). Z-DEVD-fmk, L-NMMA, and $\mathrm{N}^{\mathrm{G}}$-monomethyl-Darginine (D-NMMA) were purchased from Calbiochem (San Diego, California). Cell Tracker Green CMFDA 
and dihydrotetramethylrosamine (H2TMRos) were purchased from Molecular Probes, Inc.(Eugene, Oregon). Penicillin G, streptomycin sulfate, amphotericin $B$, and Ficoll-Paque Plus were purchased from Amersham Pharmacia Biotech. (Uppsala, Sweden), and Fico-Lite Monocytes was purchased from Atlanta Biologics (Atlanta, Georgia). Diff-Quick was purchased from Baxter (McGaw, Illinois), and limulus amoebocyte lysate assay was purchased from BioWhittaker (Walkersville, Maryland).

\section{HRPE Cell Culture}

HRPE cells were isolated from donors who had healthy eyes within 24 hours of death as previously described, in accordance with the Helsinki agreement (Elner et al, 1990). In brief, the sensory retina was separated gently from the HRPE monolayer, and the HRPE cells were removed from Bruch's membrane using 1-hour incubation with papain $(5 \mu \mathrm{g} / \mathrm{ml})$. Isolated HRPE cells were seeded into Falcon Primaria flasks in DMEM containing 15\% FBS, penicillin G (100 U/ml), streptomycin sulfate $(100 \mu \mathrm{g} / \mathrm{ml})$, and amphotericin B $(0.25 \mu \mathrm{g} / \mathrm{ml})$. The HRPE monolayers exhibited uniform immunohistochemical staining for fibronectin, laminin, and type IV collagen in a chicken wire distribution, characteristic for these epithelial cells. Cells, grown in culture up to six passages, were used for all experiments.

\section{Monocyte Culture}

Human monocytes were isolated as previously described, in accordance with the Helsinki agreement (Lukacs et al, 1995; Yoshida et al, 2001a, 2001b). Peripheral blood was drawn into a heparinized syringe from healthy volunteers and diluted 1:1 in normal saline, and mononuclear cells were separated by density gradient centrifugation (Ficoll-Paque Plus). The cells were washed and then layered onto a density gradient $(1.068 \mathrm{~g} / \mathrm{ml})$ for the enrichment of monocytes (Fico-Lite Monocytes). The isolated cells were then washed, cytospun onto a glass slide, stained with Diff-Quick, and differentially counted.

\section{Cell Stimulation}

When desired, HRPE cells and monocytes were primed with rhIFN- $\gamma$ for 24 and 12 hours, respectively, before co-culture. In some experiments, HRPE cells were prelabeled with CellTracker Green CMFDA before co-culture as described previously (Duffield et al, 2000, 2001). Cell cultures were washed with medium lacking serum and then incubated for 1 hour in serumfree medium containing CMFDA at $3 \mu \mathrm{m}$. Cells were washed in medium containing $10 \%$ FBS to remove any unbound CMFDA. Experiments were conducted in DMEM/F12 containing 10\% FBS. Enriched monocyte populations were layered onto HRPE monolayers grown to confluency. Co-cultures were incubated in control medium or in the same medium also containing rhIFN- $\gamma(500 \mathrm{U} / \mathrm{ml})$ for 48 hours. In experiments in which function-blocking monoclonal antibodies di- rected against ICAM-1 (30 $\mu \mathrm{g} / \mathrm{ml}), \mathrm{VCAM}-1(25 \mu \mathrm{g} / \mathrm{ml})$, CD18 (10 $\mu \mathrm{g} / \mathrm{ml})$, TNF- $\alpha(1 \mu \mathrm{g} / \mathrm{ml}), \mathrm{IL}-1 \beta(1 \mu \mathrm{g} / \mathrm{ml})$, and TRAIL $(100 \mathrm{ng} / \mathrm{ml})$ were used, they were incubated with HRPE cells and monocytes for 1 hour before addition of monocytes and maintained during stimulation. L-NMMA (1 mm), D-NMMA (1 mm), and SOD (100 and $1000 \mathrm{U} / \mathrm{ml}$ ) were incubated with HRPE cells and monocytes for 30 minutes before co-cultures. To detect whether cell contact was obligatory for apoptosis induction, HRPE cells and monocytes were coincubated in the same cultures but separated by porous polycarbonate filters. Cold $\mathrm{Ca}^{2+}, \mathrm{Mg}^{2+}$-free PBS including $0.5 \%$ EDTA was used to separate monocytes from HRPE cells for caspase-3 activity analysis and Western blot analysis as previously described (Yoshida et al, 2001a). The isolated cells were cytospun onto a glass slide, stained with Diff-Quick, and counted. The purity of the cells was more than 95\%. Cytokines and reagents were negative for endotoxin contamination as determined by the limulus amoebocyte lysate assay method $(<0.05 \mathrm{EU} / \mathrm{ml})$.

\section{Assessment of Apoptosis}

Morphologic Criteria. At the end of the experiment, cultures in wells were fixed by adding $4 \%$ paraformaldehyde, stored at $4^{\circ} \mathrm{C}$ for 24 hours to ensure firm adherence of the fixed apoptotic cells to the cultures. Subsequently, medium was removed and PI in PBS (5 $\mu \mathrm{g} / \mathrm{ml}$ ) was added for 5 minutes to stain both monocytes and RPE cells. This reagent was then discarded, and wells were covered with a fluorescent mountant. Using inverted fluorescent microscopy, five fields were randomly and blindly selected from each well so that at least 500 RPE cells were counted in each well. We defined RPE cells as cells labeled with green fluorescence and larger than monocytes. Apoptotic cells were clearly distinguishable by characteristic morphology, namely, cytoplasmic blebbing, cell shrinkage, nuclear condensation, and fragmentation.

TUNEL Staining. TUNEL was performed according to the manufacturer's protocol. Briefly, cultures were fixed and incubated with TUNEL mixtures containing TdT and fluorescein-labeled dNTP for 1 hour at $37^{\circ} \mathrm{C}$. Incorporated fluorescein was detected by antifluorescein antibody from sheep conjugated with horseradish peroxidase using the substrate diaminobenzidine. HRPE cells were distinguished by the subsequent labeling with anti-vimentin antibody. After the cultures were incubated with anti-vimentin antibody for 1 hour at $37^{\circ} \mathrm{C}$, alkaline phosphatase-labeled polymer (DAKO EnVision Labeled Polymer; DAKO Company, Carpinteria, California) was added to the co-cultures. After substrate reaction (New Fuchsin; DAKO Company) stained cells were analyzed under a light microscope.

Immunohistochemistry. Fixed cells prelabeled with Cell Tracker Green CMFDA were incubated for 1 hour at $37^{\circ} \mathrm{C}$ with monoclonal anti-PCNA antibody. Bound antibodies were distinguished by the subsequent incubation with rhodamine-conjugated anti-mouse IgG (ICN Pharmaceuticals, Inc., Aurora, Ohio). 


\section{Caspase-3 Activity}

Caspase-3 activity was assayed using a caspase-3 cellular activity assay kit (Biomol), according to the manufacturer's protocol. Briefly, cell extracts were added to the microtiter wells, and reaction was initiated by adding $200 \mu \mathrm{m}$ Ac-DEVD-pNA substrate. In parallel, the samples were reacted with this substrate in the presence of $0.1 \mu \mathrm{M}$ Ac-DEVD-CHO, a specific caspase-3 inhibitor, to measure the nonspecific hydrolysis of the substrate. Absorbance was read at 405 $\mathrm{nm}$ in a microtiter plate reader at the indicated time intervals.

\section{Western Blot Analysis}

HRPE cells were lysed with lysing buffer containing 50 mм HEPES (pH 7.4), 1\% Triton X-100, 0.15 м sodium chloride, $10 \%$ glycerol, $1.5 \mathrm{~mm}$ magnesium chloride, 1 mM EDTA, $1 \mathrm{~mm}$ sodium orthovanadate, $10 \mathrm{~mm}$ sodium pyrophosphate, $1 \mathrm{~mm}$ AEBSF, $10 \mathrm{~mm}$ sodium fluoride, $10 \mu \mathrm{g} / \mathrm{ml}$ aprotinin, and $10 \mu \mathrm{g} / \mathrm{ml}$ leupeptin. Lysates were then incubated on ice for 15 minutes with shaking. Then, the extracts were centrifuged at $15,000 \mathrm{rpm}$ for 15 minutes at $4^{\circ} \mathrm{C}$.

Western blot analysis of cellular extracts from HRPE cells followed the manufacturer's procedure. Briefly, samples containing $20 \mu \mathrm{g}$ of proteins were analyzed by SDS-PAGE and then were electrotransferred to nitrocellulose membranes. For signal protein detection, samples were blocked with a solution of Trisbuffered saline containing $5 \%$ dry nonfat milk and $0.1 \%$ Tween-20 (TBST) at room temperature for 1 hour, probed with anti-caspase-3 antibody, and washed three times in TBST. The membranes were incubated with horseradish peroxidase-conjugated secondary antibody for 1 hour at room temperature and washed three times with TBST. The membranes were then visualized using an enhanced chemiluminescent technique.

\section{ROM Production Determination}

HRPE cells were incubated in phenol red-free media to prevent interference with the fluorescence measurements. H2TMRos was used as fluorescence marker for ROM in HRPE cells. HRPE cells were incubated for 2 hours in media, containing $1 \mu \mathrm{g} / \mathrm{ml}$ H2TMRos. Before co-incubation this media was replaced with H2TMRos-free media. Fluorescence was measured using a PTI Photomultiplier Detection System connected to Zeiss Axiovert-inverted fluorescent microscope, enhanced by quarts optical elements. We used $530 \mathrm{~nm}$ excitation and 590 emission wavelengths. Measuring were performed in a circle ( $d=$ $100 \mu \mathrm{m}$ area) of the activated monocyte-HRPE contact $(n=10)$ after monocyte contact. When SOD was used, the media containing SOD was replaced with SOD-free media immediately before microscopy to eliminate the "quenching" effect of SOD on emitted fluorescence.

\section{Statistical Analysis}

Individual experiments were performed in triplicate three times on three different HRPE cell lines and human monocytes isolated from the blood of three different donors on separate days. Each cell line displayed similar fold-increases or decreases over control levels. Data are expressed as mean \pm SD. Various assay conditions were evaluated using ANOVA with a post-hoc analysis (Scheff multiple comparison test); $p$ values $<0.05$ were considered to be statistically significant.

\section{References}

Alnemri ES (1997). Mammalian cell death proteases: A family of highly conserved aspartate specific cysteine proteases. J Cell Biochem 64:33-42.

Arantes RM, Lourenssen S, Machado CR, and Blennerhassett MG (2000). Early damage of sympathetic neurons after co-culture with macrophages: A model of neuronal injury in vitro. Neuroreport 11:177-181.

Barak A, Morse LS, and Goldkorn T (2001). Ceramide: A potential mediator of apoptosis in human retinal pigment epithelial cells. Invest Ophthalmol Vis Sci 42:247-254.

Baudouin C, Peyman GA, Fredj-Reygrobellet D, Gordon WC, Lapalus P, Gastaud P, and Bazan NG (1992). Immunohistological study of subretinal membranes in age-related macular degeneration. Jpn J Ophthalmol 36:443-451.

Beatty S, Koh H, Phil M, Henson D, and Boulton M (2000). The role of oxidative stress in the pathogenesis of agerelated macular degeneration. Surv Ophthalmol 45:115-134.

Behar-Cohen FF, Heydolph S, Faure V, Droy-Lefaix MT, Courtois Y, and Goureau O (1996). Peroxynitrite cytotoxicity on bovine retinal pigmented epithelial cells in culture. Biochem Biophys Res Commun 226:842-849.

Bernasconi S, Peri G, Sironi M, and Mantovani A (1991). Involvement of leukocyte (beta 2) integrins (CD18/CD11) in human monocyte tumoricidal activity. Int J Cancer 49:267273.

Boker T, Augustin AJ, Breipohl W, Spitznas M, and Lutz J (1994). Increased lipid peroxide level and myeloperoxidase activity in the vitreous of patients suffering from proliferative vitreoretinopathy. Graefes Arch Clin Exp Ophthalmol 232: 652-656.

Brysk MM, Selvanayagam P, Arany I, Brysk H, Tyring SK, and Rajaraman S (1995). Induction of apoptotic nuclei by interferon-gamma and by predesquamin in cultured keratinocytes. J Interferon Cytokine Res 15:1029-1035.

Chan CC, BenEzra D, Hsu SM, Palestine AG, and Nussenblatt RB (1985). Granulomas in sympathetic ophthalmia and sarcoidosis: Immunohistochemical study. Arch Ophthalmol 103:198-202.

Cryns V and Yuan J (1998). Proteases to die for. Genes Dev 12:1551-1570.

Damle NK, Klussman K, Leytze G, Aruffo A, Linsley PS, and Ledbetter JA (1993a). Costimulation with integrin ligands intercellular adhesion molecule-1 or vascular cell adhesion molecule-1 augments activation-induced death of antigenspecific CD4 ${ }^{+}$T lymphocytes. J Immunol 151:2368-2379. 
Damle NK, Leytze G, Klussman K, and Ledbetter JA (1993b). Activation with superantigens induces programmed death in antigen-primed $\mathrm{CD}^{+}{ }^{+}$class $\mathrm{II}^{+}$major histocompatibility complex T lymphocytes via a CD11a/CD18-dependent mechanism. Eur J Immunol 23:1513-1522.

Diez-Roux G and Lang RA (1997). Macrophages induce apoptosis in normal cells in vivo. Development 124:36333638.

Drunat S, Moatti N, Paul JL, Cogny A, Benoit MO, and Demuth K (2001). Homocysteine-induced decrease in endothelin-1 production is initiated at the extracellular level and involves oxidative products. Eur J Biochem 268:52875294.

Duffield JS, Erwig LP, Wei X, Liew FY, Rees AJ, and Savill JS (2000). Activated macrophages direct apoptosis and suppress mitosis of mesangial cells. J Immunol 164:2110-2119.

Duffield JS, Ware CF, Ryffel B, and Savill J (2001). Suppression by apoptotic cells defines tumor necrosis factormediated induction of glomerular mesangial cell apoptosis by activated macrophages. Am J Pathol 159:1397-1404.

Elner SG and Elner VM (1996). The integrin superfamily and the eye. Invest Ophthalmol Vis Sci 37:696-701.

Elner SG, Elner VM, Pavilack MA, Todd RF 3rd, Mayo-Bond L, Franklin WA, Strieter RM, Kunkel SL, and Huber AR (1992). Modulation and function of intercellular adhesion molecule-1 (CD54) on human retinal pigment epithelial cells. Lab Invest 66:200-211.

Elner SG, Strieter RM, Elner VM, Rollins BJ, Del Monte MA, and Kunkel SL (1991). Monocyte chemotactic protein gene expression by cytokine-treated human retinal pigment epithelial cells. Lab Invest 64:819-825.

Elner VM, Schaffner T, Taylor K, and Glagov S (1981). Immunophagocytic properties of retinal pigment epithelium cells. Science 211:74-76.

Elner VM, Strieter RM, Elner SG, Baggiolini M, Lindley I, and Kunkel SL (1990). Neutrophil chemotactic factor (IL-8) gene expression by cytokine-treated retinal pigment epithelial cells. Am J Pathol 136:745-750.

Esser P, Heimann K, Bartz-schmidt KU, Fontana A, Schraermeyer U, Thumann G, and Weller M (1997). Apoptosis in proliferative vitreoretinal disorders: Possible involvement of TGF-beta-induced RPE cell apoptosis. Exp Eye Res 65:365378.

Feinman R, Henriksen-DeStefano D, Tsujimoto M, and Vilcek $J(1987)$. Tumor necrosis factor is an important mediator of tumor cell killing by human monocytes. J Immunol 138:635640.

Fernandes-Alnemri T, Litwack G, and Alnemri ES (1994). CPP32, a novel human apoptotic protein with homology to Caenorhabditis elegans cell death protein Ced-3 and mammalian interleukin-1 beta-converting enzyme. J Biol Chem 269:30761-30764.

Frisch SM and Ruoslahti E (1997). Integrins and anoikis. Curr Opin Cell Biol 9:701-706.

Garcia-Lloret MI, Winkler-Lowen B, and Guilbert LJ (2000). Monocytes adhering by LFA-1 to placental syncytiotrophoblasts induce local apoptosis via release of TNF-alpha: A model for hematogenous initiation of placental inflammations. J Leukoc Biol 68:903-908.
Gastman BR, Johnson DE, Whiteside TL, and Rabinowich H (2000). Tumor-induced apoptosis of T lymphocytes: Elucidation of intracellular apoptotic events. Blood 95:2015-2023.

Goureau O, Lepoivre M, Becquet F, and Courtois Y (1993). Differential regulation of inducible nitric oxide synthase by fibroblast growth factors and transforming growth factor beta in bovine retinal pigmented epithelial cells: Inverse correlation with cellular proliferation. Proc Natl Acad Sci USA 90:4276-4280.

Griffith TS, Wiley SR, Kubin MZ, Sedger LM, Maliszewski CR, and Fanger NA (1999). Monocyte-mediated tumoricidal activity via the tumor necrosis factor-related cytokine, TRAIL. J Exp Med 189:1343-1354.

Hansson M, Asea A, Ersson U, Hermodsson S, and Hellstrand K (1996). Induction of apoptosis in NK cells by monocyte-derived reactive oxygen metabolites. J Immunol 156:42-47.

Harper FH, Liversidge J, Thomson AW, and Forrester JV (1992). Interphotoreceptor retinoid binding protein induced experimental autoimmune uveitis: An immunophenotypic analysis using alkaline phosphatase anti-alkaline phosphatase staining, dual immunofluorescence and confocal microscopy. Curr Eye Res 11:129-134.

Harris MS, Sakamoto T, Kimura H, He S, Spee C, Gopalakrishna R, Gundimeda U, Yoo JS, Hinton DR, and Ryan SJ (1996). Hypericin inhibits cell growth and induces apoptosis in retinal pigment epithelial cells: Possible involvement of protein kinase C. Curr Eye Res 15:255-262.

Hirano S (1998). Nitric oxide-mediated cytotoxic effects of alveolar macrophages on transformed lung epithelial cells are independent of the beta 2 integrin-mediated intercellular adhesion. Immunology 93:102-108.

Hyun HJ, Sohn JH, Ha DW, Ahn YH, Koh JY, and Yoon YH (2001). Depletion of intracellular zinc and copper with TPEN results in apoptosis of cultured human retinal pigment epithelial cells. Invest Ophthalmol Vis Sci 42:460-465.

Jaffe GJ, Roberts WL, Wong HL, Yurochko AD, and Cianciolo GJ (1995). Monocyte-induced cytokine expression in cultured human retinal pigment epithelial cells. Exp Eye Res 60:533-543.

Jerdan JA, Pepose JS, Michels RG, Hayashi H, de Bustros S, Sebag M, and Glaser BM (1989). Proliferative vitreoretinopathy membranes: An immunohistochemical study. Ophthalmology 96:801-810.

Jin GF, Hurst JS, and Godley BF (2001). Hydrogen peroxide stimulates apoptosis in cultured human retinal pigment epithelial cells. Curr Eye Res 22:165-173.

Jonjic N, Jilek P, Bernasconi S, Peri G, Martin-Padura I, Cenzuales S, Dejana E, and Mantovani A (1992). Molecules involved in the adhesion and cytotoxicity of activated monocytes on endothelial cells. J Immunol 148:2080-2083.

Kampik A, Kenyon KR, Michels RG, Green WR, and de la Cruz ZC (1981). Epiretinal and vitreous membranes: comparative study of 56 cases. Arch Ophthalmol 99:1445-1454.

Kaven CW, Spraul CW, Zavazava NK, Lang GK, and Lang GE (2000). Growth factor combinations modulate human retinal pigment epithelial cell proliferation. Curr Eye Res 20:480487.

Kebers F, Lewalle JM, Desreux J, Munaut C, Devy L, Foidart $\mathrm{JM}$, and Noel A (1998). Induction of endothelial cell apoptosis by solid tumor cells. Exp Cell Res 240:197-205. 
Kenarova B, Voinov L, Apostolov C, Vladimirova R, and Misheva A (1997). Levels of some cytokines in subretinal fluid in proliferative vitreoretinopathy and rhegmatogenous retinal detachment. Eur J Ophthalmol 7:64-67.

Kim MC, Kabeer NH, Tandhasetti MT, Kaplan HJ, and Bora NS (1995). Immunohistochemical studies on melanin associated antigen (MAA) induced experimental autoimmune anterior uveitis (EAAU). Curr Eye Res 14:703-710.

Kishi H, Mishima HK, and Yamashita U (1994). Growth regulation of retinal pigment epithelial (RPE) cells in vitro. Curr Eye Res 13:661-668.

Lang RA and Bishop JM (1993). Macrophages are required for cell death and tissue remodeling in the developing mouse eye. Cell 74:453-462.

Liu NP, Fitzgibbon F, Nash M, and Osborne NN (1992). Epidermal growth factor potentiates the transmitter-induced stimulation of C-AMP and inositol phosphates in human pigment epithelial cells in culture. Exp Eye Res 55:489-497.

Lukacs NW, Strieter RM, Elner V, Evanoff HL, Burdick MD, and Kunkel SL (1995). Production of chemokines, interleukin-8 and monocyte chemoattractant protein-1, during monocyte: Endothelial cell interactions. Blood 86:27672773.

Matsumoto K, Shimmura S, Goto E, Saito K, Takeuchi T, Miyajima S, Negi A, and Tsubota K (1998). Lecithin-bound superoxide dismutase in the prevention of neutrophil- induced damage of corneal tissue. Invest Ophthalmol Vis Sci 39:30-35.

Mene P, Festuccia F, Polci R, Pugliese F, and Cinotti GA (2002). Transmembrane signalling in human monocyte/ mesangial cell co-cultures: Role of cytosolic $\mathrm{Ca}(2+)$. Nephrol Dial Transplant 17:42-49.

Meszaros AJ, Reichner JS, and Albina JE (2000). Macrophage-induced neutrophil apoptosis. J Immunol 165: 435-441.

Nakayama M, Kayagaki N, Yamaguchi N, Okumura K, and Yagita H (2000). Involvement of TWEAK in interferon gammastimulated monocyte cytotoxicity. J Exp Med 192:13731380.

Noble KE, Wickremasinghe RG, DeCornet C, Panayiotidis P, and Yong KL (1999). Monocytes stimulate expression of the $\mathrm{Bcl}-2$ family member, $\mathrm{A} 1$, in endothelial cells and confer protection against apoptosis. J Immunol 162:1376-1383.

Ongkosuwito JV, Feron EJ, van Doornik CE, Van der Lelij A, Hoyng CB, La Heij EC, and Kijlstra A (1998). Analysis of immunoregulatory cytokines in ocular fluid samples from patients with uveitis [see comments]. Invest Ophthalmol Vis Sci 39:2659-2665.

Osusky R and Ryan SJ (1996). Retinal pigment epithelial cell proliferation: Potentiation by monocytes and serum. Graefes Arch Clin Exp Ophthalmol 234(Suppl 1):S76-S82.

Palmer EM, Farrokh-Siar L, Maguire van Seventer J, and van Seventer GA (2001). IL-12 decreases activation-induced cell death in human naive Th cells costimulated by intercellular adhesion molecule-1. I. IL-12 alters caspase processing and inhibits enzyme function. J Immunol 167:749-758.

Peri G, Chiaffarino F, Bernasconi S, Padura IM, and Mantovani A (1990). Cytotoxicity of activated monocytes on endothelial cells. J Immunol 144:1444-1448.
Ramachandran A, Moellering D, Go YM, Shiva S, Levonen AL, Jo H, Patel RP, Parthasarathy S, and Darley-Usmar VM (2002). Activation of C-Jun N-terminal kinase and apoptosis in endothelial cells mediated by endogenous generation of hydrogen peroxide. Biol Chem 383:693-701.

Rao NA, Romero JL, Fernandez MA, Sevanian A, and Marak GE Jr (1987). Role of free radicals in uveitis. Surv Ophthalmol 32:209-213.

Reddy VM, Zamora RL, and Kaplan HJ (1995). Distribution of growth factors in subfoveal neovascular membranes in agerelated macular degeneration and presumed ocular histoplasmosis syndrome. Am J Ophthalmol 120:291-301.

Robbins SG, Brem RB, Wilson DJ, O'Rourke LM, Robertson JE, Westra I, Planck SR, and Rosenbaum JT (1994). Immunolocalization of integrins in proliferative retinal membranes. Invest Ophthalmol Vis Sci 35:3475-3485.

Salisbury SM and Calhoun WJ (1990). Modulation of human peripheral blood monocyte superoxide release by interferongamma and lipopolysaccharide. Wis Med J 89:271-274.

Schwegler JS, Knorz MC, Akkoyun I, and Liesenhoff $\mathrm{H}$ (1997). Basic, not acidic fibroblast growth factor stimulates proliferation of cultured human retinal pigment epithelial cells. Mol Vis 3:10.

Seshiah PN, Kereiakes DJ, Vasudevan SS, Lopes N, Su BY, Flavahan NA, and Goldschmidt-Clermont PJ (2002). Activated monocytes induce smooth muscle cell death: Role of macrophage colony-stimulating factor and cell contact. Circulation 105:174-180.

Shen WY, Yu MJ, Barry CJ, Constable IJ, and Rakoczy PE (1998). Expression of cell adhesion molecules and vascular endothelial growth factor in experimental choroidal neovascularisation in the rat. $\mathrm{Br} \mathrm{J}$ Ophthalmol 82:1063-1071.

Sparrow JR and Cai B (2001). Blue light-induced apoptosis of A2E-containing RPE: Involvement of caspase-3 and protection by Bcl-2. Invest Ophthalmol Vis Sci 42:1356-1362.

Susin SA, Zamzami N, Castedo M, Daugas E, Wang HG, Geley S, Fassy F, Reed JC, and Kroemer G (1997). The central executioner of apoptosis: Multiple connections between protease activation and mitochondria in Fas/APO-1/ CD95- and ceramide-induced apoptosis. J Exp Med 186:2537.

Thibeault A, Zekki H, Mourad W, Charron D, and Al-Daccak R (1999). Triggering HLA-DR molecules on human peripheral monocytes induces their death. Cell Immunol 192:79-85.

Thornberry NA and Lazebnik Y (1998). Caspases: Enemies within. Science 281:1312-1316.

Vinores SA, Campochiaro PA, McGehee R, Orman W, Hackett SF, and Hjelmeland LM (1990). Ultrastructural and immunocytochemical changes in retinal pigment epithelium, retinal glia, and fibroblasts in vitreous culture. Invest Ophthalmol Vis Sci 31:2529-2545.

Von Eynatten K and Bauer G (2001). Central and ambivalent role of hydrogen peroxide during intercellular induction of apoptosis. Int J Oncol 18:1169-1174.

Walzog B, Jeblonski F, Zakrzewicz A, and Gaehtgens P (1997). Beta2 integrins (CD11/CD18) promote apoptosis of human neutrophils. FASEB J 11:1177-1186.

Wang J, Beekhuizen $\mathrm{H}$, and van Furth R (1994). Surface molecules involved in the adherence of recombinant interferon-gamma (rIFN-gamma)-stimulated human mono- 
cytes to vascular endothelial cells. Clin Exp Immunol 95:263269.

Wang JF, Jerrells TR, and Spitzer JJ (1996). Decreased production of reactive oxygen intermediates is an early event during in vitro apoptosis of rat thymocytes. Free Radic Biol Med 20:533-542.

Webb DS and Gerrard TL (1990). IFN-alpha and IFN-gamma can affect both monocytes and tumor cells to modulate monocyte-mediated cytotoxicity. J Immunol 144:3643-3648.

Wood JP and Osborne NN (2001). The influence of zinc on caspase-3 and DNA breakdown in cultured human retinal pigment epithelial cells. Arch Ophthalmol 119:81-88.

Wu MX, Ao Z, Hegen M, Morimoto C, and Schlossman SF (1996). Requirement of Fas(CD95), CD45, and CD11a/CD18 in monocyte-dependent apoptosis of human T cells. J Immunol 157:707-713.

Yamashita H, Hori S, and Masuda K (1986). Population and proportion of component cells in preretinal membranes. Jpn J Ophthalmol 30:269-281.
Yoshida A, Elner SG, Bian ZM, Kunkel SL, Lukacs NW, and Elner VM (2001a). Thrombin regulates chemokine induction during human retinal pigment epithelial cell/monocyte interaction. Am J Pathol 159:1171-1180.

Yoshida A, Elner SG, Bian Z-M, Kunkel SL, Lukacs NW, and Elner VM (2001b). Differential chemokine regulation by Th2 cytokines during human RPE-monocyte co-culture. Invest Ophthalmol Vis Sci 42:1631-1638.

Zachrisson K, Neopikhanov V, Samali A, and Uribe A (2001). Interleukin-1, interleukin-8, tumour necrosis factor alpha and interferon gamma stimulate DNA synthesis but have no effect on apoptosis in small-intestinal cell lines. Eur J Gastroenterol Hepatol 13:551-559.

Zheng TS, Hunot S, Kuida K, and Flavell RA (1999). Caspase knockouts: Matters of life and death. Cell Death Differ 6:1043-1053. 